\title{
NUMERICAL SIMULATION OF THE PROCESS
}

OF A TECHNICAL OBJECT STATE CHANGES

\section{NUMERYCZNA SYMULACJA REALIZACJI PROCESU ZMIAN STANÓW OBIEKTU TECHNICZNEGO}

\author{
Bogdan Landowski
}

University of Science and Technology, Bydgoszcz, Poland,

\begin{abstract}
The article presents a construction method and an example of a model of a technical object operation process as well as the main stochastic assumption which is a mathematical model of an object state changes. The model of the operation process was built using an analysis of the state space and operationrelated events of the analyzed technical objects. An example of numerical simulation of the technical object state change process as a tool to be used to support the analysis of the considered process. Numerical simulation of the stochastic process being a model of a technical object state change process makes it possible to determine the process characteristics impossible to determine in an analytical way.
\end{abstract}

Keywords: numerical simulation, operation process, stochastic process, object state, operation-related state

Streszczenie: $W$ artykule przedstawiono sposób budowy i przykład modelu procesu eksploatacji obiektów technicznych oraz podstawowe założenia procesu stochastycznego będacego matematycznym modelem zmian stanów obiektu. Model procesu eksploatacji zostat zbudowany na podstawie analizy przestrzeni stanów oraz zdarzeń eksploatacyjnych dotyczacych analizowanych obiektów technicznych. Przedstawiono przykład numerycznej symulacji realizacji procesu zmian stanów obiektu technicznego jako narzędzia wspomagającego analizy rozważanego procesu. Numeryczna symulacja realizacji procesu stochastycznego będacego modelem procesu zmian stanów obiektu technicznego umożliwia wyznaczania charakterystyk procesu niemożliwych do wyznaczenia droga analityczna.

Stowa kluczowe: numeryczna symulacja, proces eksploatacji, proces stochastyczny, stan obiektu, stan eksploatacyjny 
Numerical simulation of the process of a technical object state changes

Numeryczna symulacja realizacji procesu zmian stanów obiektu technicznego

\section{NUMERICAL SIMULATION OF THE PROCESS OF A TECHNICAL OBJECT STATE CHANGES}

\section{Introduction}

Operation processes of complex technical objects involve many operational states which are significant for their operational efficiency. Moreover, the systems of technical objects operation and maintenance are of tem characterized by a complex structure. When analyzing complex technical systems, different kinds of failures need to be considered. It is also important to provide a mathematical model representing state changes of an analyzed object in order to be able to predict the impact of control decision and other operational events, e.g. failures, of the technical system, operation process and its efficiency.

Analytical determination of the operation process characteristics, on the basis of mathematical models of these processes, needs complex calculations and it is impossible for a big number of operational states and transitions between them it is often impossible.

Random process $\mathrm{X}(\mathrm{t})$ with a finite space of states $\mathrm{S}$ and a set of parameters $\mathrm{R}+$ (subset of real numbers $\square 0$ ) is a natural model of the operation process of objects of many technical categories $[12,13]$.

Random stochastic processes, including a homogenous Markov and semi-Markov processes $[2,3,4,5,8,6,11-13]$, are commonly used for modeling of operational states.

Usually homogenous processes with a small number of states and/or transitions between them are analyzed due to the need to perform complicated calculations for an increasing number of states and possible transitions between them.

Numerical simulation of the process of technical object operational state changes for the accepted model enables to perform calculations for a big number of states and possible transitions between them and for the process characterized by nonhomogeneity.

In this article, assumptions and essentials of a numerical simulation of the process of technical object operational state changes are presented. A semi-Markov process is a mathematical model of the process of technical object state changes.

Numerical simulation of the considered process makes it possible to make analyses for different distributions of random variables denoting duration time of the analyzed states. At the same time it enables to make analyses of weight and variability of criteria and external factors affecting the process of a technical object operation. It allows to provide assessment of the process and the technical system behavior for different sets of input data which model the impact of different forcing factors including decision related and external ones. Under specific conditions and for properly estimated input data sets and for fulfillment of the accepted 
mathematical model assumptions, a numerically simulated model can fairly well reflect the real situation.

The research object is a real system of a city bus transport system in a medium size urban agglomeration. This system is one of the subsystems of the city public transport system and its transport means are the analyzed technical objects. Identification of the considered transport means operation process allowed to distinguish definite sets of operational states and events significant for their operational efficiency $[6-10,12,13]$.

Sets of source data necessary to formulate the model assumptions and its initial verification were obtained using the method of passive experiment in a real research object.

Due to space limitations, only the main assumptions of the developed method have been presented.

\section{Operational states of a city bus}

Identification of the city bus transport system operation and its processes allowed to identify operational states, distinguished according to the accepted significance criterion. These states are characterized in the following way [8-10, 13]:

- $\mathrm{S}_{1}$ - state of a technical object active operation; technical object and its operator accomplish a transport task. Territorial range of the task is described by a number, the so called transport route, whereas the time range by the schedule;

- $S_{2}$ - state of the object's waiting for a unit of the so called technical emergency service; unusable object which is in the technical system (on its territory) waits for a technical emergency unit or moves with its operator to the place of the unit location;

- $S_{3}$ - state of the object's being repaired inside the technical system; an unusable technical object undergoes actions in order to provide it with usability; a technical object is renovated by technical emergency workers or is towed to a diagnostic station or service station (that belong to the technical system );

- $\mathrm{S}_{4}$ - state of the object's waiting for renovation to be performed within the system; unusable object is waiting for the renovation process to started in the usability assurance subsystem ;

- $\mathrm{S}_{5}$ - state of the object's being under renovation when the repair is being performed within the operation system, unusable technical object is renovated in the usability assurance subsystem.

- $\mathrm{S}_{6}$ - state of the object's waiting for pre-repair diagnosis; a technical object waits for the process of diagnosis to begin in the usability assurance subsystem;

- $\mathrm{S}_{7}$ - state of pre-repair diagnosis of the technical object; a technical object undergoes diagnosis in the subsystem of usability assurance; 
- $\mathrm{S}_{8}$ - state of the technical object's waiting for post-repair diagnosis; a technical object waits for the control diagnosis process to begin;

- $\mathrm{S}_{9}$ - state of the object's post-repair diagnosis; a technical object undergoes the process of control diagnosis; in the analyzed operation system after performance of renovation processes of given subsystems of the vehicle undergo the so called post-repair diagnosis (to control correctness of the repair);

- $\mathrm{S}_{10}$ - state of the object's being serviced on the day of operation, a technical object undergoes a process of the so called daily servicing in the subsystem of usability assurance; and prior diagnosis is being performed in order to prevent occurrence of failures during accomplishment of the transport task, this state results from the operation strategy implemented in the system of city transport;

- $\mathrm{S}_{11}$ - state of the object's waiting to begin accomplishment of the transport task; after being provided with the state of usability a technical object does not perform the scheduled task due to the method of transport task organization;

- $\mathrm{S}_{12}$ - state of a technical object's standby due to unsuitability of the environment; a usable technical object does no perform the scheduled transport task because of an event preventing accomplishment of the transport task which occurred in the environment of the technical system:

- $\mathrm{S}_{13}$ - state of organizational standby of a technical object; the state results from specificity of the scheduled transport tasks.

An assumption has been accepted that each operated technical object can, in any time moment $t$, be only in one of the distinguished states.

The sequence of successive operational states, frequency of their occurrence, as well as other characteristics of the operation process connected with the object state including costs to be borne and profits to be gained for an object's being in a given state, largely depend on the individual character of particular technical objects, characteristics of the processes the objects undergo and the features and structures of subsystems used in the operation process $[6,8-10,13]$.

Possible transitions between the analyzed operational states of a bus are characterized by the time of their duration as well as costs and incomes per a time unit involved in being in particular states. A change of an object state (entrance to a state) can be connected with gaining income or bearing a cost.

\section{Model of the operation process}

A mathematical model of the process of a technical object state changes is a stochastic process $\left\{X_{t}, t \in R+\right\}$ with a finite space of states $S$.

It was assumed that the analyzed stochastic process $\left\{X_{t}, t \in R+\right\}$ is a semi-Markov process. General characteristics of semi-Markov processes and justification of their 
application possibilities to be used for an analysis of technical objects operation can be found in many works including [2-6, 8, 11-13].

Since a formal description of the process of operational state changes of complex technical objects, including city bus transport vehicles, and a model of this process in the form of a stochastic process $\left\{\mathrm{X}_{\mathrm{t}}, \mathrm{t} \in \mathrm{R}+\right\}$, whose values are technical states and operational states with practical importance, are presented in works such as $[6,8,12,13]$, in this study only selected features of the analyzed process have been presented.

The basic property of semi-Markov process $\left\{\mathrm{X}_{\mathrm{t}}, \mathrm{t} \in \mathrm{R}+\right\}$ can be defined as follows: for a given state of the process in time $\tau_{\mathrm{n}}$ the duration time of an actual state and the state reached in time $\tau_{\mathrm{n}+1}$ do not depend stochastically on the process states in times $\tau_{0}, \tau_{1}, \ldots, \tau_{\mathrm{n}-1}$ and on duration times of previous states, which can be expressed in the following way:

$$
\begin{aligned}
& P\left\{X\left(\tau_{n+1}\right)=j, \tau_{n+1}-\tau_{n}<t / X\left(\tau_{n}\right)=i\right\}= \\
& =P\left\{X\left(\tau_{n+1}\right)=j, \tau_{n+1}-\tau_{n}<t / X\left(\tau_{n}\right)=i, X\left(\tau_{n-1}\right)=i_{n-1}, \quad X\left(\tau_{1}\right)=i_{1}, X\left(\tau_{0}\right)=i_{0}\right\},
\end{aligned}
$$

where:

$\mathrm{S}=\{1,2,3, \ldots, \mathrm{k}\}$ - set of states of $\mathrm{X}(\mathrm{t})$ process,

$0=\tau_{0}<\tau_{1}<\tau_{2}<\tau_{3} \ldots<\tau_{\mathrm{n}}<\ldots$ - random variables to denote occurrence times of $\mathrm{X}(\mathrm{t})$ process state changes,

$\mathrm{j}, \mathrm{i}, \mathrm{i}_{\mathrm{n}-1}, \mathrm{i}_{\mathrm{n}-2}, \ldots \mathrm{i}_{1}, \mathrm{i}_{0} \in \mathrm{S}=\{1,2,3, \ldots, \mathrm{k}\}$

$n-$ number of pace in which a change of process $X(t)$ state occurs, $n \in N$,

$\mathrm{N}-$ set of natural numbers.

$T_{i j}$ is a random variable denoting duration time of $i \in S$ of $\left\{X_{t}, t \in R+\right\}$, process when the next state will be $j \in S$ state. Distribution of $T_{i j}$ random variable is defined by $\mathrm{F}_{\mathrm{ij}}(\mathrm{t})$ distribution function.

From the point of view of the study goal, it is convenient to describe unequivocally the analyzed semi-Markov process through defining elements $(\mathrm{p}, \mathrm{P}, \mathrm{F}(\mathrm{t}))$ denoting: - $p$ - stochastic vector of initial distribution:

$$
\mathrm{p}=\left[\mathrm{p}_{\mathrm{i}}: \mathrm{i} \in \mathrm{S}\right], \mathrm{p}_{\mathrm{i}}=\mathrm{P}\{\mathrm{X}(0)=\mathrm{i}\}, \quad \mathrm{i} \in \mathrm{S}=\left\{\begin{array}{llll}
2 & 3 & 1 . & \mathrm{k}, . . \sum_{\mathrm{i}=1}^{\mathrm{k}} \mathrm{p}_{\mathrm{i}}
\end{array}\right.
$$

- P - transition probability matrix of Markov chain inserted in $\left\{X_{t}, t \in R+\right\}$ process:

$$
P=\left[p_{i j}: i, j \in S\right], p_{i}=P\left\{X\left(\tau_{n+1}\right)=j / X\left(\tau_{n}\right)=i\right\},
$$


- $F(t)$ - distribution function matrix of distributions of $T_{i j}, i, j \in S$ random variables denoting duration time of the process state $\left\{X_{t}, t \in R+\right\}$ if state $j$ is the successive state:

$$
F(t)=\left[F_{i}(t): i, j \in S\right], F_{i}(t)=P\left\{T_{i}<j t\right\}=P\left\{\tau_{n+1}-\tau_{n}<t / X\left(\tau_{n+1}\right)=j, X\left(\tau_{n}\right)=i\right\} .
$$

The following relations result from the definition of a semi-Markov process $[4,5]$ :

$$
\begin{aligned}
& Q_{i}(j t)=p_{i} F_{j i}(t), i, j \in S, t \in R+, \\
& \sum_{j \in S} Q_{i j}(t)=F_{i}(t) \text { for } i \in S, t \in R+.
\end{aligned}
$$

Matrix $Q(t)=\left[Q_{i}(t): i, j \in S\right]$ is called a nucleus of a semi-Markov process.

Function $F_{i}(t)$ is a distribution function of state $i \in S$ duration time. Random variable denoting duration time of $i \in S$ state whose distribution is defined by $F_{i}(t)$ distribution function is denoted by $T_{i}$.

Moreover, it was assumed that a model of operational state changes of an n-set of homogenous (from the point of view of this study) technical objects are independent $\left\{\mathrm{X}_{\mathrm{t}}, \mathrm{t} \in \mathrm{T}\right\}$ processes.

Random vector:

$$
\mathbf{X}(\mathrm{t})=\left[\mathrm{X}_{1}(\mathrm{t}), \mathrm{X}_{2}(\mathrm{t}), \ldots, \mathrm{X}_{\mathrm{n}}(\mathrm{t})\right],
$$

describes the process of operational state changes of a set of objects $[6,12]$.

In order to provide assessment of economic aspects of the operation process modeling it is necessary to additionally determine appropriate values of economic categories connected with the manner of entrance to the process states and being in them.

Characteristics of the process are used as indexes which allow to analyze and investigate the process of operational state changes whose model is a semi Markov process $\left\{\mathrm{X}_{\mathrm{t}}, \mathrm{t} \in \mathrm{R}+\right\}$.

In practical applications it is necessary to find out whether there are reasons to reject the assumptions resulting from the applied mathematical apparatus.

For the described assumptions, a simulation of the process of a single technical object operation involves simulation of the described stochastic process $\left\{\mathrm{X}_{\mathrm{t}}, \mathrm{t} \in \mathrm{R}+\right\}$ being a model of the process of a technical object operational state changes.

A computer software has been developed to enable simulation of so described stochastic process. Values of selected sets of indicators enabling an analysis of the modeled process are determined during simulation of the process of state changes. 
In the developed program of numerical simulation of $\left\{X_{t}, t \in R+\right\}$ process the following distributions of $\mathrm{T}_{\mathrm{ij}}$ random variables have been implemented: exponential, normal, lognormal, Weibull and gamma.

\section{Numerical simulation of the operation process - calculation example}

Research experiments included numerical simulation of stochastic process $\left\{\mathrm{X}_{t}, \mathrm{t} \in \mathrm{R}+\right\}$ which is a mathematical model of the process of operational state changes of the analyzed technical objects. A set of index values of the analyzed process was determined during the simulation.

The distinguished separable subsets of vehicles, which for the purpose of this study goal can be treated as homogenous objects, were called categories in order to improve clarity of the description. It was assumed that the object category includes vehicles of the same type with a similar service potential.

The values of the model parameters were estimated on the basis of results of initial experimental tests performed in a real city bus transport system.

In the analyzed case, $i \in S$ states of $\left\{X_{t}, t \in R+\right\}$ process correspond to the distinguished operational states $\mathrm{S}_{\mathrm{i}}, \mathrm{i}=1,2, \ldots ., 13$ of the bus operation.

For simulation experiments it was assumed that a vehicle's being in $S_{1}$ state is connected with gaining profits whereas its being in the remaining states involves costs to be borne by the technical system operating the vehicle.

Numerical simulation of the operation process by means of a computer simulation program allows to determine values of the set of input indexes for different values of input quantities. The values of selected operational indexes such as: summary duration time of repairs, repair costs, incomes from transport task services, number of repairs and others, were input values for the analyzed time interval, determined during simulation for the analyzed time interval.

Due to the character of this study and for the purpose of improving clarity of the presented example, the simulation experiments were performed with the assumption that the time of being in a given state does not depend on the successive state of the process, that is, $\mathrm{F}_{\mathrm{ij}}(\mathrm{t})=\mathrm{F}_{\mathrm{i}}(\mathrm{t}), \mathrm{i}, \mathrm{j} \in \mathrm{S}=\{1,2, \ldots, 13\}$. The assumption was that distributions of the time of an object's being in particular states are of gamma type. To verify consistence of the hypothesis of the empirical distribution with gamma distribution, $\chi^{2}$ goodness of fit test and Kolomogorov $\chi$ were used.

Since on Sunday and official holidays the bus schedules are different, simulation experiments were performed for a time corresponding to an annual provision of transport services. In 2017 there are 250 weekdays. The selected simulation results presented in further part of this work concern $<0, t_{k}>, t_{k}=6000$ hours. 
Numerical simulation of the process of a technical object state changes Numeryczna symulacja realizacji procesu zmian stanów obiektu technicznego

Tab. 1 Summary number of entrances to particular states of the analyzed category of objects

\begin{tabular}{|c|r|r|}
\hline Code of state & \multicolumn{1}{|c|}{ Category I } & \multicolumn{1}{c|}{ Category II } \\
\hline 1 & 3275625 & 31115.625 \\
\hline 2 & 5715.625 & 4271.875 \\
\hline 3 & 5962.5 & 4334.375 \\
\hline 4 & 5268.75 & 3168,75 \\
\hline 5 & 8034.375 & 5803.125 \\
\hline 6 & 2934.375 & 1868.75 \\
\hline 7 & 3353.125 & 1943,75 \\
\hline 8 & 253.125 & 159.375 \\
\hline 9 & 2381.25 & 1546,875 \\
\hline 10 & 22665.625 & 24215.625 \\
\hline 11 & 5984.375 & 4646.875 \\
\hline 12 & 81.25 & 43.75 \\
\hline 13 & 25025 & 25790625 \\
\hline
\end{tabular}

Tab. 2 Total profit generated by the system for the analyzed category of objects [PLN]

\begin{tabular}{|c|c|}
\hline Category I & Category II \\
\hline 86135.30 & 111975.89 \\
\hline
\end{tabular}

In order to perform simulation experiments, estimation of the model input parameters values that is: the process initial distribution, probability matrix of transitions between the process states, parameters of random variables denoting time of the objects being in particular operational states and unit profits connected with a technical object's being in the analyzed states.

To perform a simulation of exchange of worn-out buses for new ones, an estimation of the above presented quantities was made for two subsets of vehicles referred to as categories.

The first subset (category 1) covers vehicles considered to be new, whose service period was from 2 to 4 years, whereas the second subset (category 2) covers vehicles considered to be worn out whose service time was from 8 to 10 years.

Simulations of the operation process were performed for 100 buses. Selected simulation results are presented in tables from 1 to 3 .

Exchange of worn-out buses for new vehicles leads to a positive value change of the analyzed indexes. It needs to be stressed that the costs involved in the exchange of buses were not included in determination of the economic index values. 
Tab. 3 Summary duration time of particular operational states for the analyzed category of objects $[\mathrm{h}]$

\begin{tabular}{|c|r|r|}
\hline Code of state & \multicolumn{1}{c|}{ Category I } & \multicolumn{1}{c|}{ Category II } \\
\hline 1 & 376692.41 & 399935.38 \\
\hline 2 & 1760.25 & 1027.16 \\
\hline 3 & 3600.41 & 2810.03 \\
\hline 4 & 17844.56 & 7708.94 \\
\hline 5 & 25450.69 & 14721.91 \\
\hline 6 & 317.16 & 202.13 \\
\hline 7 & 771,88 & 425.81 \\
\hline 8 & 26.34 & 1.12 .1963 \\
\hline 9 & 435.22 & 275.03 \\
\hline 10 & 213.91 & 2247.81 \\
\hline 11 & 2094.59 & 2151.28 \\
\hline 12 & 137.78 & 74.28 \\
\hline 13 & 171018.91 & 170348.72 \\
\hline
\end{tabular}

It needs to be assumed that the values of random variable distribution parameter values used in the example and some other data needed for simulation are of hypothetical character. The parameter values have been estimated on the basis of a small size data set.

The presented results of a numerical simulation of the process of bus operational state changes are supposed to illustrate the considerations presented in this paper. A set of indexes to be determined includes subsets of indexes such as: availability, repair time, task accomplishment efficiency, costs and others.

\section{Conclusions}

It seems that the use of numerical simulation for representation of the process of a technical object operational state changes can for the presented model be a significant tool to support analyses of reliability, availability and safety.

Forecasting the impact of different decision variants on the operation process and its efficiency involves numerical simulation of the object operational state changes for the analyzed model estimated values of parameters and determination (every time) of values of the analyzed technical and economic efficiency.

Numerical simulation of the process of a technical object state changes can be applied to other, than the considered here, technical objects, their drive systems and other devices or processes for which analytical analysis based on mathematical models is impossible or pointless.

Both technical, operational and other states can come under consideration. 
Numerical simulation of the process of a technical object state changes Numeryczna symulacja realizacji procesu zmian stanów obiektu technicznego

Results of performed simulations confirm the expected responses of the model to value changes of its parameters. It confirms usefulness of the model in qualitative and quantitative analysis of decision variants to be used in transport systems.

The presented method, with developed algorithms and computer tools, can be used to solve a wide range of problems connected with operation of machines and devices. It relates mainly to economic issues, risk and safety management of complex technical systems as well as an analysis of availability and reliability of technical objects.

\section{References}

[1] Buslenko, N., Kałasznikow, W., Kowalenko, I.: Theory of complex systems. PWN, Warsaw 1979.

[2] Girtler J.: Physical aspect of application and usefulness of semi-Markovian processes for modeling the processes occurring in operational phase of technical objects. Polish Maritime Research 2004, nr 3(41), vol. 11, pp. 25-30.

[3] Girtler J.: Stochastyczny model procesu eksploatacji okrętowego silnika spalinowego. Zagadnienia Eksploatacji Maszyn 1989 nr 2, s. 79-88.

[4] Grabski F.: Semi-markowskie modele niezawodności i eksploatacji. PAN IBS, seria: Badania Systemowe, t. 30, Warszawa 2002.

[5] Grabski F.: Teoria semi-markowskich procesów eksploatacji obiektów technicznych. Zeszyty Naukowe AMW, nr 75 A, Gdynia 1982.

[6] Landowski B., Woropay M., Neubauer A.: Sterowanie niezawodnością w systemach transportowych. Biblioteka Problemów Eksploatacji, Wydawnictwo Instytutu Eksploatacji Maszyn, Bydgoszcz - Radom 2004.

[7] Landowski B.: An example of a technical object operation process model describing influence of engine damages on the operation process course. Journal of POLISH CIMAC Vol. 9, No. 3, Gdańsk 2014.

[8] Landowski B.: Metoda wyznaczania wartości wybranych zmiennych decyzyjnych do racjonalnego sterowania procesem eksploatacji realizowanym w systemie transportowym. Praca doktorska, ATR, Bydgoszcz.

[9] Landowski B.: Model eksploatacji pewnej klasy obiektów technicznych. Zeszyty Naukowe Nr 229, Mechanika 48, Wydawnictwa Uczelniane ATR w Bydgoszczy, Bydgoszcz 2000, pp. 21-35.

[10] Landowski B.: Zarys metody wyznaczania wartości zmiennych decyzyjnych w systemach eksploatacji autobusów komunikacji miejskiej. Zeszyty Naukowe $\mathrm{Nr}$ 229, Mechanika 48, Wydawnictwa Uczelniane ATR w Bydgoszczy, Bydgoszcz 2000, pp.5-19.

[11] Rudnicki J.: Application issues of the semi-markov reliability model. Polish Maritime Research 2015, nr 1(85), vol. 22, pp. 55-64. 
[12] Woropay M., Grabski F., Landowski B.: Semi-Markov model of the vehicle maintenance processes in an urban transport system. Scientific Publishers of the Polish Scientific Association of Automotive Engineering, Archives of Automotive Engineering Vol. 7, No 3, 2004.

[13] Woropay M., Knopik L., Landowski B.: Modelowanie procesów eksploatacji w systemie transportowym. Biblioteka Problemów Eksploatacji. Wydawnictwo Instytutu Eksploatacji Maszyn, Bydgoszcz - Radom 2001.

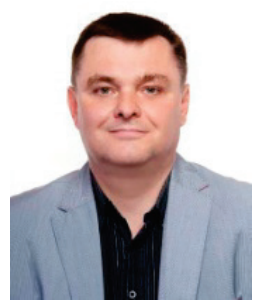

Bogdan Landowski, Ph.D, works in the Department of Transport and Machine Maintenance of the Faculty of Mechanical Engineering in the University of Science and Technology in Bydgoszcz. His scientific work deals with the problems of complex maintenance systems effectiveness, as well as of modelling of maintenance processes and systems. The research area covers application of Markov decision process theory for mathematical modelling of maintenance processes. His scientific investigations are focused on numerical modelling of maintenance processes and systems. 
Numerical simulation of the process of a technical object state changes

Numeryczna symulacja realizacji procesu zmian stanów obiektu technicznego

\section{NUMERYCZNA SYMULACJA REALIZACJI PROCESU ZMIAN STANÓW OBIEKTU TECHNICZNEGO}

\section{Wstęp}

Analizując procesy eksploatacji większości złożonych obiektów technicznych oraz przestrzenie stanów eksploatacyjnych tych obiektów można wyróżnić często wiele istotnych dla efektywności eksploatacji stanów eksploatacyjnych. Ponadto systemy eksploatacji obiektów technicznych często charakteryzują się złożona strukturą. Zależnie od potrzeb, analizując złożone systemy eksploatacji, rozważane są różne rodzaje uszkodzeń użytkowanych obiektów.

Istotnym problemem $\mathrm{w}$ analizie złożonych systemów eksploatacji obiektów technicznych i procesów w nich realizowanych jest budowa matematycznego modelu zmian stanów obiektu pozwalającego przewidywać wpływ oddziaływań sterujących oraz różnych zdarzeń eksploatacyjnych, np. uszkodzeń na przebieg procesu eksploatacji i efektywność działania systemu eksploatacji.

Analityczne wyznaczanie charakterystyk procesu eksploatacji na podstawie badań matematycznych modeli tych procesów jest złożone obliczeniowo, a w przypadku dużej liczby analizowanych stanów procesu i możliwych przejść pomiędzy stanami często niemożliwe.

Naturalnym modelem procesu eksploatacji wielu kategorii obiektów technicznych jest proces losowy $\mathrm{X}(\mathrm{t})$ o skończonej przestrzeni stanów $\mathrm{S}$ i zbiorze parametrów $\mathrm{R}+$ (podzbiór liczb rzeczywistych $\geq 0)[12,13]$.

Powszechnie do modelowania zmian stanów eksploatacyjnych stosowane są jednorodne procesy stochastyczne, w tym jednorodne procesy Markowa i semiMarkowa [2, 3, 4, 5, 8, 6, 11-13].

Ze względu na znaczną komplikację obliczeń przy zwiększającej się liczbie analizowanych stanów i możliwych przejść między stanami na ogół analizuje się procesy jednorodne o niewielkiej liczbie stanów i/lub przejść pomiędzy stanami procesu.

Numeryczna symulacja realizacji procesu zmian stanów obiektu technicznego dla przyjętego modelu umożliwia zarówno realizację obliczeń dla dużej liczby analizowanych stanów i możliwych przejść między stanami jak i dla procesów charakteryzujących się niejednorodnością.

$\mathrm{W}$ artykule przedstawiono założenia $\mathrm{i}$ istotę numerycznej symulacji realizacji procesu zmian stanów obiektu technicznego. Matematycznym modelem procesu zmian stanów obiektu jest proces semi-Markowa.

Numeryczna symulacja realizacji procesu zmian stanów obiektu technicznego pozwala na realizację analiz dla różnych rozkładów zmiennych losowych oznaczających czas trwania analizowanych stanów. Jednocześnie umożliwia prowadzenie analiz uwzględniających wagę i zmienność kryteriów oraz czynników zewnętrznych mających wpływ na przebieg procesu eksploatacji obiektu technicznego. 
Umożliwia ocenę zachowania się procesu i systemu eksploatacji, w którym obiekty są użytkowane dla różnych zbiorów danych wejściowych modelujących oddziaływanie wymuszeń sterujący oraz zewnętrznych. Dla właściwie oszacowanych zbiorów danych wejściowych oraz przy spełnieniu założeń przyjętego modelu matematycznego procesu eksploatacji numeryczna symulacja może, w określonych warunkach, dobrze przybliżać model do sytuacji rzeczywistej.

Obiektem badań jest rzeczywisty system eksploatacji autobusów komunikacji miejskiej w średniej wielkości aglomeracji miejskiej. System ten jest jednym z podsystemów systemu komunikacji miejskiej. Analizowanymi obiektami technicznymi są środki transportu. W wyniku identyfikacji procesu eksploatacji badanych środków transportu wyróżniono skończone zbiory stanów oraz zdarzeń eksploatacyjnych istotnych dla efektywności ich eksploatacji [6-10, 12, 13].

Zbiory danych źródłowych, niezbędnych do opracowania założeń modelu i jego wstępnej weryfikacji, uzyskano w wyniku realizacji badań eksploatacyjnych metodą eksperymentu biernego w rzeczywistym obiekcie badań.

Ze względu na ograniczoną objętość opracowania przedstawiono tylko podstawowe założenia opracowanej metody.

\section{Stany eksploatacyjne autobusu komunikacji miejskiej}

W wyniku identyfikacji systemu eksploatacji autobusów komunikacji miejskiej i realizowanych w nim procesów eksploatacji zdefiniowano wyróżnione, w aspekcie przyjętego kryterium istotności, stany eksploatacyjne. Stany te scharakteryzowano następująco [8-10, 13]:

- $\mathrm{S}_{1}$ - stan czynnego użytkowania obiektu technicznego; obiekt techniczny wraz $\mathrm{z}$ operatorem realizują przydzielone im zadanie przewozowe. Zakres terytorialny zadania przewozowego jest określony numerem tzw. trasy komunikacyjnej, natomiast czasowy numerami kursów, zgodnie z obowiązującym rozkładem jazdy;

- $\mathrm{S}_{2}$ - stan oczekiwania obiektu technicznego na jednostkę tzw. pogotowia technicznego; niezdatny zadaniowo obiekt techniczny znajdujący się $\mathrm{w}$ otoczeniu systemu eksploatacji (w sensie terytorialnym) oczekuje na przybycie jednostki terenowych służb lotnych lub wraz $\mathrm{z}$ operatorem przemieszcza się do miejsca postoju tej jednostki;

- $\mathrm{S}_{3}$ - stan odnowy obiektu technicznego realizowanej w otoczeniu systemu eksploatacji; niezdatny zadaniowo obiekt techniczny znajdujący się w otoczeniu systemu eksploatacji podlega działaniom, zmierzającym do przywrócenia mu stanu zdatności zadaniowej; obiekt techniczny podlega odnowie realizowanej przez pracowników terenowych służb lotnych lub jest holowany do stacji diagnostycznej lub stacji obsługi (należących do systemu eksploatacji);

- $\mathrm{S}_{4}$ - stan oczekiwania obiektu technicznego na odnowę realizowaną w systemie eksploatacji; niezdatny zadaniowo obiekt techniczny oczekuje na rozpoczęcie realizacji procesu odnowy w podsystemie zapewniania zdatności; 
Numerical simulation of the process of a technical object state changes

Numeryczna symulacja realizacji procesu zmian stanów obiektu technicznego

- $\mathrm{S}_{5}$ - stan odnowy obiektu technicznego realizowanej w systemie eksploatacji, niezdatny zadaniowo obiekt techniczny podlega odnowie w podsystemie zapewniania zdatności;

- $\mathrm{S}_{6}$ - stan oczekiwania obiektu technicznego na diagnozowanie przednaprawcze; obiekt techniczny oczekuje na rozpoczęcie realizacji procesu diagnozowania w podsystemie zapewniania zdatności;

- $\mathrm{S}_{7}$ - stan diagnozowania przednaprawczego obiektu technicznego; obiekt techniczny podlega procesowi diagnozy w podsystemie zapewniania zdatności;

- $\mathrm{S}_{8}$ - stan oczekiwania obiektu technicznego na diagnozowanie ponaprawcze; obiekt techniczny oczekuje na rozpoczęcie realizacji procesu diagnozowania kontrolnego;

- $\mathrm{S}_{9}$ - stan diagnozowania ponaprawczego obiektu technicznego; obiekt techniczny podlega procesowi diagnozowania kontrolnego; w badanym systemie eksploatacji po realizacji procesów odnowy wyróżnionych podsystemów pojazdu realizowane jest tzw. diagnozowanie ponaprawcze (jako kontrola poprawności realizacji procesu odnowy);

- $\mathrm{S}_{10}$ - stan obsługiwania $\mathrm{w}$ dniu użytkowania, obiekt techniczny $\mathrm{w}$ podsystemie zapewniania zdatności podlega procesowi tzw. obsługi codziennej oraz realizowane są czynności diagnozowania uprzedzającego $\mathrm{w}$ celu zapobieżenia występowania uszkodzeń w trakcie realizacji zadania przewozowego, stan ten wynika $\mathrm{z}$ realizowanej $\mathrm{w}$ badanym systemie komunikacji miejskiej strategii eksploatacji;

- $\mathrm{S}_{11}$ - stan oczekiwania obiektu technicznego na podjęcie realizacji zadania przewozowego; obiekt techniczny po przywróceniu mu stanu zdatności nie wykonuje zaplanowanego zadania przewozowego ze względu na sposób organizacji zadań przewozowych;

- $\mathrm{S}_{12}$ - stan oczekiwania obiektu technicznego ze względu na niezdatność otoczenia; zdatny zadaniowo obiekt techniczny nie realizuje zaplanowanego zadania przewozowego w wyniku zajścia $\mathrm{w}$ otoczeniu systemu eksploatacji zdarzenia uniemożliwiającego realizację tego zadania;

- $\mathrm{S}_{13}$ - stan postoju organizacyjnego obiektu technicznego; stan ten wynika ze specyfiki podjętych zadań przewozowych określonych tzw. rozkładem jazdy.

Przyjęto założenie, że każdy z eksploatowanych obiektów technicznych może, $\mathrm{w}$ danej chwili czasu t, znajdować się tylko w jednym $\mathrm{z}$ wyróżnionych stanów eksploatacyjnych, tworzących zbiór stanów procesu.

Sekwencja kolejnych stanów eksploatacyjnych, przedziały czasu trwania stanów, częstości ich występowania, a także inne cechy procesu eksploatacji związane ze stanami obiektu, w tym ponoszone koszty czy osiągane przychody gdy obiekt znajduje się w określonym stanie, zależne są przede wszystkim od indywidualnych cech poszczególnych obiektów technicznych, cech procesów jakim te obiekty podlegają oraz od cech i struktury podsystemów, współdziałających w realizacji procesu eksploatacji $[6,8-10,13]$. 
Wyznaczono możliwe przejścia pomiędzy analizowanym stanami eksploatacyjnymi autobusu. Stany eksploatacyjne charakteryzowane są czasem ich trwania oraz nakładami i przychodami na jednostkę czasu związanymi z przebywaniem w stanach. Zmiana stanu obiektu (wejście do stanu) może być związane z uzyskaniem przychodu lub poniesieniem nakładu.

\section{Model procesu eksploatacji}

Matematycznym modelem procesu zmian stanów eksploatacyjnych obiektu technicznego jest proces stochastyczny $\left\{\mathrm{X}_{\mathrm{t}}, \mathrm{t} \in \mathrm{R}+\right\}$ o skończonej przestrzeni stanów S.

Przyjęto założenie, że analizowany proces stochastyczny $\left\{\mathrm{X}_{\mathrm{t}}, \mathrm{t} \in \mathrm{R}+\right\}$ jest procesem semi-Markowa.

W wielu pracach, w tym [2-6, 8, 11-13] przedstawione są ogólne własności procesów semimarkowskich i uzasadnienia możliwości ich zastosowania do analizy procesów eksploatacji obiektów technicznych.

Ponieważ formalny opis procesu zmian stanów technicznych i eksploatacyjnych złożonych obiektów technicznych, w tym autobusów komunikacji miejskiej oraz model tego procesu $\mathrm{W}$ postaci procesu stochastycznego $\left\{\mathrm{X}_{\mathrm{t}}, \mathrm{t} \in \mathrm{R}+\right\}$, którego wartościami są występujące $\mathrm{w}$ czasie eksploatacji stany techniczne i eksploatacyjne mające istotne znaczenie praktyczne przedstawiono, między innymi w pracach $[6,8,12,13]$, to w niniejszym opracowaniu przedstawiono tylko wybrane cechy analizowanego procesu.

Podstawową własność procesu semi-Markowa $\left\{\mathrm{X}_{\mathrm{t}}, \mathrm{t} \in \mathrm{R}+\right\}$ można zdefiniować następująco: przy znanym stanie procesu $\mathrm{w}$ chwili $\tau_{\mathrm{n}}$ czas trwania aktualnego stanu oraz stan osiągnięty $\mathrm{w}$ chwili $\tau_{\mathrm{n}+1}$ nie zależą stochastycznie od stanów procesu w chwilach $\tau_{0}, \tau_{1}, \ldots, \tau_{\mathrm{n}-1}$ oraz od czasów trwania poprzednich stanów, co można zapisać następująco:

$$
\begin{aligned}
& P\left\{X\left(\tau_{n+1}\right)=j, \tau_{n+1}-\tau_{n}<t / X\left(\tau_{n}\right)=i\right\}= \\
& =P\left\{X\left(\tau_{n+1}\right)=j, \tau_{n+1}-\tau_{n}<t / X\left(\tau_{n}\right)=i, X\left(\tau_{n-1}\right)=i_{n-1}, \ldots, X\left(\tau_{1}\right)=i_{1}, X\left(\tau_{0}\right)=i_{0}\right\},
\end{aligned}
$$

gdzie:

$\mathrm{S}=\{1,2,3, \ldots, \mathrm{k}\}$ - zbiór stanów procesu $\mathrm{X}(\mathrm{t})$,

$0=\tau_{0}<\tau_{1}<\tau_{2}<\tau_{3} \ldots<\tau_{\mathrm{n}}<\ldots$ - zmienne losowe oznaczające chwile, w których następują zmiany stanów procesu $\mathrm{X}(\mathrm{t})$,

$\mathrm{j}, \mathrm{i}, \mathrm{i}_{\mathrm{n}-1}, \mathrm{i}_{\mathrm{n}-2}, \ldots \mathrm{i}_{1}, \mathrm{i}_{0} \in \mathrm{S}=\{1,2,3, \ldots, \mathrm{k}\}$

$\mathrm{n}$ - numer kroku, w którym następuje zmiana stanu procesu $\mathrm{X}(\mathrm{t}), \mathrm{n} \in \mathrm{N}$,

$\mathrm{N}-$ zbiór liczb naturalnych. 
Numerical simulation of the process of a technical object state changes Numeryczna symulacja realizacji procesu zmian stanów obiektu technicznego

Przez $T_{i j}$ oznaczono zmienną losową oznaczającą czas trwania stanu $i \in S$ procesu $\left\{\mathrm{X}_{\mathrm{t}}, \mathrm{t} \in \mathrm{R}+\right\}$, gdy następnym stanem będzie stan $\mathrm{j} \in \mathrm{S}$. Rozkład zmiennej losowej $\mathrm{T}_{\mathrm{ij}}$ określony jest przez dystrybuantę $\mathrm{F}_{\mathrm{ij}}(\mathrm{t})$.

$\mathrm{Z}$ punktu widzenia celu pracy wygodnie jest jednoznacznie opisać analizowany proces semi-Markowa poprzez określenie elementów ( $\mathrm{p}, \mathrm{P}, \mathrm{F}(\mathrm{t}))$ oznaczających:

- p - wektor stochastyczny rozkładu początkowego:

$$
\mathrm{p}=\left[\mathrm{p}_{\mathrm{i}}: \mathrm{i} \in \mathrm{S}\right], \mathrm{p}_{\mathrm{i}}=\mathrm{P}\{\mathrm{X}(0)=\mathrm{i}\}, \quad \mathrm{i} \in \mathrm{S}=\{1,2,3, \ldots, \mathrm{k}\}, \quad \sum_{\mathrm{i}=1}^{\mathrm{k}} \mathrm{p}_{\mathrm{i}}=1,
$$

- P - macierz prawdopodobieństw przejść włożonego $\mathrm{W}$ proces $\left\{\mathrm{X}_{\mathrm{t}}, \mathrm{t} \in \mathrm{R}+\right\}$ łańcucha Markowa:

$$
P=\left[p_{i j}: i, j \in S\right], p_{i j}=P\left\{X\left(\tau_{n+1}\right)=j / X\left(\tau_{n}\right)=i\right\},
$$

- $F(t)$ - macierz dystrybuant rozkładów zmiennych losowych $T_{i j}, i, j \in S$ oznaczających czas trwania stanu i procesu $\left\{\mathrm{X}_{\mathrm{t}}, \mathrm{t} \in \mathrm{R}+\right\}$ jeżeli kolejnym stanem będzie stan j:

$$
F(t)=\left[F_{i j}(t): i, j \in S\right], F_{i j}(t)=P\left\{T_{i j}<t\right\}=P\left\{\tau_{n+1}-\tau_{n}<t / X\left(\tau_{n+1}\right)=j, X\left(\tau_{n}\right)=i\right\}
$$

$\mathrm{Z}$ definicji procesu semiMarkowa wynikają związki $[4,5]$ :

$$
\begin{aligned}
& Q_{i j}(t)=p_{i j} F_{i j}(t), \quad i, j \in S, t \in R+, \\
& \sum_{j \in S} Q_{i j}(t)=F_{i}(t) d l a i \in S, t \in R+.
\end{aligned}
$$

$\operatorname{Macierz} Q(t)=\left[Q_{i j}(t): i, j \in S\right]$ nazywana jest jądrem procesu semi-Markowa.

Funkcja $\mathrm{F}_{\mathrm{i}}(\mathrm{t})$ jest dystrybuantą rozkładu czasu trwania stanu $\mathrm{i} \in \mathrm{S}$. Zmienną losową oznaczającą czas trwania stanu $i \in S$, o rozkładzie określonym przez dystrybuantę $\mathrm{F}_{\mathrm{i}}(\mathrm{t})$ oznaczono symbolem $\mathrm{T}_{\mathrm{i}}$.

Ponadto przyjęto założenie, że modelem zmian stanów eksploatacyjnych zbioru $n$ jednorodnych z punktu widzenia celu badań obiektów technicznych są niezależne procesy $\left\{\mathrm{X}_{\mathrm{t}}, \mathrm{t} \in \mathrm{T}\right\}$.

Wektor losowy:

$$
\mathbf{X}(\mathrm{t})=\left[\mathrm{X}_{1}(\mathrm{t}), \mathrm{X}_{2}(\mathrm{t}), \ldots, \mathrm{X}_{\mathrm{n}}(\mathrm{t})\right]
$$

opisuje proces zmian stanów eksploatacyjnych zbioru obiektów $[6,12]$. 
W celu oceny aspektów ekonomicznych związanych z realizacją modelowanego procesu eksploatacji należy dodatkowo określić odpowiednie wartości kategorii ekonomicznych związanych ze sposobem wejścia do stanów procesu oraz przebywaniem w nich.

Jako wskaźniki pozwalające na analizy i badania procesu zmian stanów eksploatacyjnych, którego modelem jest proces semimarkowski $\left\{\mathrm{X}_{\mathrm{t}}, \mathrm{t} \in \mathrm{R}+\right\}$ stosuje się charakterystyki tego procesu.

W zastosowaniach praktycznych należy zweryfikować czy nie ma podstaw do odrzucenia założeń wynikających z zastosowanego aparatu matematycznego.

Dla opisanych założeń symulacja procesu eksploatacji pojedynczego obiektu technicznego polega na symulacji realizacji opisanego procesu stochastycznego $\left\{\mathrm{X}_{\mathrm{t}}, \mathrm{t} \in \mathrm{R}+\right\}$ będącego modelem procesu zmian stanów eksploatacyjnych obiektu.

Opracowano program komputerowy umożliwiający symulację realizacji tak określonego procesu stochastycznego. W trakcie realizacji symulacji wyznaczane są wartości wybranych zbiorów wskaźników umożliwiających analizę modelowanego procesu zmian stanów obiektów.

$\mathrm{W}$ opracowanym programie numerycznej symulacji realizacji procesu $\left\{\mathrm{X}_{\mathrm{t}}, \mathrm{t} \in \mathrm{R}+\right\}$ zaimplementowano następujące rozkłady zmiennych losowych $\mathrm{T}_{\mathrm{ij}}$ : wykładniczy, normalny, lognormalny, Weibulla i gamma.

\section{Numeryczna symulacja realizacji procesu eksploatacji - przykład obliczeniowy}

Eksperymenty badawcze polegały na numerycznej symulacja realizacji procesu stochastycznego $\left\{\mathrm{X}_{\mathrm{t}}, \mathrm{t} \in \mathrm{R}+\right\}$ będącego matematycznym modelem procesu zmian stanów eksploatacyjnych analizowanych obiektów technicznych. W trakcie symulacji był wyznaczany zbiór wartości wskaźników dotyczących analizowanego procesu.

W celu zwiększenia przejrzystości opisu w dalszej części opracowania wyróżnione rozłączne podzbiory pojazdów, które można traktować jako obiekty jednorodne w aspekcie celu badań nazwano kategoriami. W opracowaniu przyjęto, że kategoria obiektów obejmuje pojazdy tego samego typu o zbliżonym potencjale użytkowym.

Wartości parametrów modelu oszacowano na podstawie wyników wstępnych badań eksploatacyjnych zrealizowanych w rzeczywistym systemie autobusowej komunikacji miejskiej.

W analizowanym przykładzie stany $\mathrm{i} \in \mathrm{S}$ procesu $\left\{\mathrm{X}_{\mathrm{t}}, \mathrm{t} \in \mathrm{R}+\right\}$ odpowiadają wyróżnionym stanom eksploatacyjnym $\mathrm{S}_{\mathrm{i}}, \mathrm{i}=1,2, \ldots ., 13$ autobusu.

$\mathrm{W}$ eksperymentach symulacyjnych przyjęto, że przebywanie pojazdu w stanie $S_{1}$ związane jest $\mathrm{z}$ uzyskiwaniem przychodów, natomiast $\mathrm{w}$ pozostałych stanach ponoszeniem nakładów przez system, w którym obiekty są eksploatowane.

Numeryczna symulacja realizacji procesu eksploatacji, za pomocą komputerowego programu symulacyjnego, pozwala na wyznaczenie wartości szeregu wskaźników dla różnych wartości wielkości wejściowych. 
Numerical simulation of the process of a technical object state changes Numeryczna symulacja realizacji procesu zmian stanów obiektu technicznego

Dla analizowanego przedziału czasu wyznaczanymi w trakcie symulacji wielkościami wyjściowymi były wartości wybranych wskaźników eksploatacyjnych, takich jak: sumaryczny czas trwania napraw, koszty napraw, przychody wynikające z realizacji zadań przewozowych, liczba napraw i inne.

Ze względu na charakter opracowania oraz zwiększenia czytelności prezentowanego przykładu eksperymenty symulacyjne wykonano przy założeniu, że czasy przebywania $\mathrm{w}$ stanach procesu nie zależą od kolejnego stanu procesu, $\mathrm{tj}$. $\mathrm{F}_{\mathrm{ij}}(\mathrm{t})=\mathrm{F}_{\mathrm{i}}(\mathrm{t}), \mathrm{i}, \mathrm{j} \in \mathrm{S}=\{1,2, \ldots, 13\}$. Przyjęto, że rozkłady czasów przebywania obiektów technicznych w poszczególnych stanach procesu mają rozkład gamma. Do weryfikacji hipotezy o zgodności rozkładu empirycznego z rozkładem gamma wykorzystano test zgodności $\chi^{2}$ oraz $\lambda$ Kołmogorowa.

Ponieważ występuje zasadniczo inny harmonogram przewozów w niedziele i dni świąteczne eksperymenty symulacyjne przeprowadzono dla przedziału czasu eksploatacji o długości odpowiadającej około rocznemu realizowaniu zadań przewozowych. W roku 2017 występuje 250 dni roboczych. Przedstawione w dalszej części opracowania wybrane wyniki symulacji dotyczą przedziału czasu $<0, \mathrm{t}_{\mathrm{k}}>, \mathrm{t}_{\mathrm{k}}=6000$ godzin.

Tab. 1 Sumaryczna liczba wejść do poszczególnych stanów dla analizowanych kategorii obiektów

\begin{tabular}{|c|r|r|}
\hline Kod stanu & \multicolumn{1}{|c|}{ Kategoria I } & \multicolumn{1}{c|}{ Kategoria II } \\
\hline 1 & 32756,25 & 31115,625 \\
\hline 2 & 5715,625 & 4271,875 \\
\hline 3 & 5962,5 & 4334,375 \\
\hline 4 & 5268,75 & 3168,75 \\
\hline 5 & 8034,375 & 5803,125 \\
\hline 6 & 2934,375 & 1868,75 \\
\hline 7 & 3353,125 & 1943,75 \\
\hline 8 & 253,125 & 159,375 \\
\hline 9 & 2381,25 & 1546,875 \\
\hline 10 & 22665,625 & 24215,625 \\
\hline 11 & 5984,375 & 4646,875 \\
\hline 12 & 81,25 & 43,75 \\
\hline 13 & 25025 & 25790,625 \\
\hline
\end{tabular}

Tab. 2 Catkowity zysk wypracowany przez system dla analizowanych kategorii obiektów [PLN]

\begin{tabular}{|c|c|}
\hline Kategoria I & Kategoria II \\
\hline 86135,30 & 111975,89 \\
\hline
\end{tabular}


W celu realizacji eksperymentów symulacyjnych dokonano estymacji wartości parametrów wejściowych modelu, tj.: rozkładu początkowego procesu, macierzy prawdopodobieństw przejść między stanami procesu, parametrów rozkładów zmiennych losowych oznaczających czas przebywania obiektów technicznych w poszczególnych stanach eksploatacyjnych i zysków jednostkowych, związanych z przebywaniem obiektów technicznych w analizowanych stanach.

W celu symulacji wymiany autobusów wyeksploatowanych na nowe dokonano estymacji w/w. wielkości dla dwóch podzbiorów użytkowanych pojazdów nazwanych kategoriami. Podzbiór pierwszy (kategoria 1) obejmuje pojazdy umownie uznane za nowe, których okres eksploatacji wynosił od 2 do 4 lat, natomiast podzbiór drugi (kategoria 2) obejmuje pojazdy umownie uznane za wyeksploatowane, których okres eksploatacji wynosił od 8 do 10 lat.

Zrealizowano przebiegi symulacyjne procesu eksploatacji 100 autobusów. Wybrane wyniki eksperymentów zestawiono w tabelach od 1 do 3.

Wymiana autobusów wyeksploatowanych na nowe obiekty prowadzi do pozytywnej zmiany wartości analizowanych wskaźników. Należy zaznaczyć, że przy wyznaczaniu wartości wskaźników ekonomicznych nie uwzględniono kosztów związanych z wymianą autobusów.

Tab. 3 Sumaryczny czas trwania poszczególnych stanów eksploatacyjnych dla analizowanych kategorii obiektów [h]

\begin{tabular}{|c|r|r|}
\hline Kod stanu & Kategoria I & \multicolumn{1}{c|}{ Kategoria II } \\
\hline 1 & 376692,41 & 399935,38 \\
\hline 2 & 1760,25 & 1027,16 \\
\hline 3 & 3600,41 & 2810,03 \\
\hline 4 & 17844,56 & 7708,94 \\
\hline 5 & 25450,69 & 14721,91 \\
\hline 6 & 317,16 & 202,13 \\
\hline 7 & 771,88 & 425,81 \\
\hline 8 & 26,34 & 12,63 \\
\hline 9 & 435,22 & 275,03 \\
\hline 10 & 2130,91 & 2247,81 \\
\hline 11 & 2094,59 & 2151,28 \\
\hline 12 & 137,78 & 74,28 \\
\hline 13 & 171018,91 & 170348,72 \\
\hline
\end{tabular}


Numerical simulation of the process of a technical object state changes Numeryczna symulacja realizacji procesu zmian stanów obiektu technicznego

Należy przyjąć, że użyte w przykładzie wartości parametrów rozkładów zmiennych losowych oraz niektórych pozostałych danych niezbędnych do symulacji mają charakter hipotetyczny. Wartości parametrów oszacowano na podstawie zbioru danych o małej liczności.

Przedstawione wyniki numerycznej symulacji realizacji procesu zmian stanów eksploatacyjnych autobusów mają charakter ilustracji rozważań prezentowanych w opracowaniu.

Zbiór możliwych do wyznaczenia wskaźników obejmuje podzbiory wskaźników dotyczących: gotowości, czasów napraw, efektywności realizacji zadań, kosztów $\mathrm{i}$ inne.

\section{Podsumowanie}

Wydaje się, iż zastosowanie numerycznej symulacji realizacji procesu zmian stanów obiektu technicznego dla przedstawionego modelu może stanowić istotne narzędzie wspomagające analizy niezawodności, gotowości i bezpieczeństwa.

Prognozowanie wpływu analizowanych, różnorodnych wariantów decyzyjnych na przebieg i efektywność procesu eksploatacji polega na numerycznej symulacji realizacji procesu zmian stanów obiektów dla oszacowanych wartości parametrów analizowanego modelu zmian stanów obiektu technicznego i wyznaczeniu każdorazowo wartości analizowanych wskaźników efektywności technicznej i ekonomicznej.

Numeryczna symulacja realizacji procesu zmian stanów obiektów może być zastosowana do innych, niż rozważanych w opracowaniu obiektów technicznych, ich układów napędowych oraz innych urządzeń czy procesów, dla których analiza analityczna opracowanych modeli matematycznych jest niemożliwa bądź niecelowa. Rozważane mogą być zarówno stany techniczne, eksploatacyjne i inne. Wyniki zrealizowanych badań symulacyjnych potwierdzają oczekiwane reakcje modelu na zmiany wartości jego parametrów. Świadczy to o przydatności modelu do jakościowej i ilościowej analizy wariantów decyzyjnych w systemach transportowych.

Przedstawiona metoda wraz $\mathrm{z}$ opracowanymi algorytmami i narzędziami informatycznymi może być zastosowana do rozwiązywania szerokiej gamy problemów związanych z eksploatacją maszyn i urządzeń. Dotyczy to przede wszystkim zagadnień ekonomicznych, zarządzania ryzykiem i bezpieczeństwem działania złożonych systemów technicznych, a także analizy gotowości i niezawodności obiektów technicznych. 


\section{Literatura}

[1] Buslenko, N., Kałasznikow, W., Kowalenko, I.: Theory of complex systems. PWN, Warsaw 1979.

[2] Girtler J.: Physical aspect of application and usefulness of semi-Markovian processes for modeling the processes occurring in operational phase of technical objects. Polish Maritime Research 2004, nr 3(41), vol. 11, pp. 25-30.

[3] Girtler J.: Stochastyczny model procesu eksploatacji okrętowego silnika spalinowego. Zagadnienia Eksploatacji Maszyn 1989 nr 2, s. 79-88.

[4] Grabski F.: Semi-markowskie modele niezawodności i eksploatacji. PAN IBS, seria: Badania Systemowe, t. 30, Warszawa 2002.

[5] Grabski F.: Teoria semi-markowskich procesów eksploatacji obiektów technicznych. Zeszyty Naukowe AMW, nr 75 A, Gdynia 1982.

[6] Landowski B., Woropay M., Neubauer A.: Sterowanie niezawodnością w systemach transportowych. Biblioteka Problemów Eksploatacji, Wydawnictwo Instytutu Eksploatacji Maszyn, Bydgoszcz - Radom 2004.

[7] Landowski B.: An example of a technical object operation process model describing influence of engine damages on the operation process course. Journal of POLISH CIMAC Vol. 9, No. 3, Gdańsk 2014.

[8] Landowski B.: Metoda wyznaczania wartości wybranych zmiennych decyzyjnych do racjonalnego sterowania procesem eksploatacji realizowanym w systemie transportowym. Praca doktorska, ATR, Bydgoszcz.

[9] Landowski B.: Model eksploatacji pewnej klasy obiektów technicznych. Zeszyty Naukowe Nr 229, Mechanika 48, Wydawnictwa Uczelniane ATR w Bydgoszczy, Bydgoszcz 2000, pp. 21-35.

[10] Landowski B.: Zarys metody wyznaczania wartości zmiennych decyzyjnych w systemach eksploatacji autobusów komunikacji miejskiej. Zeszyty Naukowe $\mathrm{Nr}$ 229, Mechanika 48, Wydawnictwa Uczelniane ATR w Bydgoszczy, Bydgoszcz 2000, pp.5-19.

[11] Rudnicki J.: Application isssues of the semi-markov reliability model. Polish Maritime Research 2015, nr 1(85), vol. 22, pp. 55-64.

[12] Woropay M., Grabski F., Landowski B.: Semi-Markov model of the vehicle maintenance processes in an urban transport system. Scientific Publishers of the Polish Scientific Association of Automotive Engineering, Archives of Automotive Engineering Vol. 7, No 3, 2004. 
Numerical simulation of the process of a technical object state changes Numeryczna symulacja realizacji procesu zmian stanów obiektu technicznego

[13] Woropay M., Knopik L., Landowski B.: Modelowanie procesów eksploatacji w systemie transportowym. Biblioteka Problemów Eksploatacji. Wydawnictwo Instytutu Eksploatacji Maszyn, Bydgoszcz - Radom 2001.

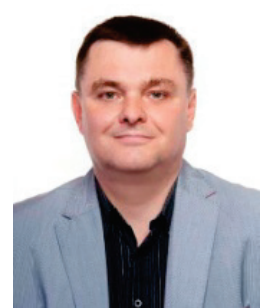

Dr inz. Bogdan Landowski pracuje $w$ Zaktadzie Transportu i Eksploatacji na Wydziale Inżynierii Mechanicznej Uniwersytetu Technologiczno-Przyrodniczego $w$ Bydgoszczy. W pracy naukowej zajmuje się problemami dotyczacymi efektywności zlożonych systemów eksploatacji oraz modelowania procesów $i$ systemów eksploatacji . Tematyka badawcza obejmuje zastosowanie teorii decyzyjnych procesów Markowa do matematycznego modelowania procesów eksploatacji. Prowadzi badania w zakresie modelowania numerycznego procesów i systemów eksploatacji. 